\title{
ANALISIS STRUKTUR KOMUNITAS MANGROVE DI KAWASAN SEKITAR PT. CONCH KABUPATEN BOLAANG MONGONDOW
}

\section{ANALYSIS OF MANGROVE COMMUNITY STRUCTURE IN AREAS AROUND PT. CONCH BOLAANG MONGONDOW REGENCY}

\author{
George L. Pandeirot ${ }^{1}$, Antonius P. Rumengan ${ }^{1}$, Carolus P. Paruntu ${ }^{1}$, Suria Darwisito ${ }^{1}$, Medy Ompi ${ }^{1}$, \\ Adnan S. Wantasen²
}

${ }^{1}$ Program Studi IImu Kelautan, FPIK UNSRAT Manado, 95115.

2Program Studi Manajemen Sumberdaya Perairan, FPIK UNSRAT Manado, 95115.

*e-mail: Georgeleonardpandeirot@Gmail.com

\begin{abstract}
This research was conducted for four months of April-July 2020. The purpose of this study was to determine species density, species relative density, species frequency, species relative frequency, species cover, species relative cover, index of the importance of mangrove species in the area around PT. Conch Lolak District, Bolaang Mongondow Regency, North Sulawesi Province. This research was conducted for four months of April-July 2020. The method used was a quadratic plot of 6 stations. Data collection at each station was made with a plot size of 10 $\times 10 \mathrm{~m} 2$ to measure the diameter of a tree at breast height $(\mathrm{DBH})$, which has a minimum trunk circumference of 16 $\mathrm{cm}$. The results showed that there were five types of mangroves, namely $R$. apiculata, $R$. mucronata, B. gymnorhiza, $S$. alba, and $X$. granatum. The highest relative density of species at station 2 , namely $R$. mucronate $62.96 \%$, while the lowest value at station 3, namely $R$. mucronata $8.77 \%$, the highest relative frequency value at station 4 , namely R. mucronata $33.33 \%$, whereas the lowest value was at station 5 , namely $B$. gymnorhiza $25.00 \%$, the highest relative closure value was at station 5, namely $R$. mucronata $30.91 \%$, while the lowest was at station 2, namely $R$. apiculata $12.88 \%$, and the important value index the highest was at station 3, namely R. apiculata $138.09 \%$ and the lowest value was at station 5 , namely X. granatum $35.05 \%$.
\end{abstract}

Kata Kunci: Mangrove, Structure in areas around PT. Conch. Conch, Rhizopora

\begin{abstract}
Abstrak
Penelitian ini dilakukan selama 4 bulan April-Juli 2020. Tujuan penelitian ini adalah untuk mengetahui kerapatan jenis, kerapatan relatif jenis, frekuensi jenis, frekuensi relatif jenis, penutupan jenis, penutupan relatif jenis, indeks nilai penting jenis mangrove yang ada di kawasan sekitar PT. Conch Kecamatan Lolak, Kabupaten Bolaang Mongondow, Provinsi Sulawawesi Utara. Penelitian ini dilakukan selama 4 bulan April-Juli 2020. Metode yang dipakai adalah plot kuadrat sebanyak 6 stasiun. Pengambilan data pada setiap stasiun dibuat plot dengan ukuran $10 \times 10 \mathrm{~m}^{2}$ untuk mengukur diameter pohon setinggi dada (DBH) yang memiliki lingkar batang minimal 16 $\mathrm{cm}$. Hasil penelitian menunjukkan bahwa ada 5 jenis mangrove yaitu $R$. apiculata, R. mucronata, $B$. gymnorhiza, $S$. alba dan $X$. granatum. Kerapatan relatif jenis tertinggi pada stasiun 2 , yaitu $R$. mucronata $62,96 \%$, sedangkan nilai terendah pada stasiun 3, yaitu $R$. mucronata $8,77 \%$, nilai Frekuensi relatif jenis tertingi pada stasiun 4 , yaitu R. mucronata $33.33 \%$, sedangkan nilai terendah pada stasiun 5 , yaitu $B$. gymnorhiza $25.00 \%$, nilai Penutupan relatif jenis tertinggi pada stasiun 5 , yaitu $R$. mucronata $30,91 \%$, sedangkan terendah pada stasiun 2 , yaitu $R$. apiculata $12,88 \%$, dan Indeks nilai penting tertinggi pada stasiun 3, yaitu $R$. apiculata $138,09 \%$ dan nilai terendah pada stasiun 5, yaitu $X$. granatum $35,05 \%$.
\end{abstract}

Kata Kunci: Mangrove, kawasan sekitar PT. Conch, Rhizopora 


\section{PENDAHULUAN}

Indonesia merupakan salah satu negara kepulauan dan memiliki banyak potensi sumber daya alam wilayah pesisisr dan laut, salah satu yaitu hutan mangrove. Perkiraan luas hutan mangrove di Indonesia, yaitu seluas 4,5 juta hektar dan bisa dibilang sebagai negara yang dengan hutan mangrove terluas di dunia melebihi Brazil (1,3 juta ha), Nigeria ( 1,1 juta ha), dan Australia (0,97 juta ha) (Nurrahman dkk., 2012). Mangrove terluas terdapat di Papua sekitar 1.350.600 ha (38 \%), Kalimantan 978.200 (28 \%) dan Sumatera 673.300 ha (19 \%) (Noor dkk., 2006).

Salah satu daerah yang ada di Sulawesi Utara yang memiliki hutan mangrove adalah daerah kawasan sekitar PT. Conch, Kecamatan Lolak, Kabupaten Bolaang Mongondow. Luasan mangrove yang ada di Kecamatan Lolak sekitar 912,44 ha (Sefle dkk., 2013). Pengaruh dan tekanan terhadap habitat mangrove yang bersumber dari keinginan manusia untuk mengkonversi areal hutan mangrove menjadi areal pemukiman, industri perikanan dan pertanian menyebabkan eksploitasi berlebihan terhadap hutan mangrove sehingga dapat mengakibatkan kerusakan ekologi di pesisir, salah satunya di pesisir Kecamatan Lolak, Kabupaten Bolaang Mongondow. Pengunaan lahan mangrove di Kecamatan Lolak, Kabupaten Bolaang Mongondow pada tahun 2012 sebesar 1.90 \% (Pappa 2011 dalam Sefle dkk., 2013).

Tujuan dari penelitian ini adalah untuk mengetahui kerapatan jenis, kerapatan relatif jenis, frekuensi jenis, frekuensi relatif jenis, penutupan jenis, penutupan relatif jenis, indeks nilai penting serta indeks nilai keanekaragaman jenis mangrove yang ada di kawasan sekitar PT. Conch Kecamatan Lolak, Kabupaten Bolaang Mongondow Provinsi Sulawawesi Utara.

\section{METODE PENELITIAN}

\section{Tempat dan Waktu Penelitian}

Waktu penelitian ini selama 4 bulan (April-Juli 2020). Tempat penelitian adalah kawasan mangrove sekitar PT. Conch Kecamatan Lolak, Kabupaten Bolaang Mongondow Provinsi Sulawawesi Utara yang secara geografis terletak pada koordinat $124^{\circ}$ 4'52,40" Bujur Timur dan 053'41,46" Lintang Utara.

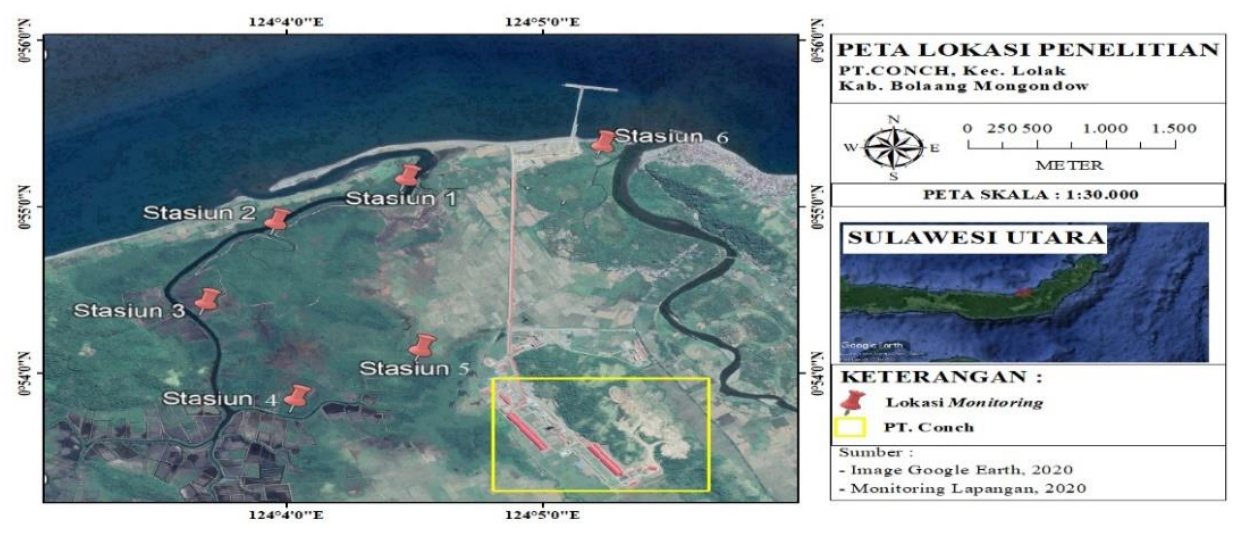

Gambar 1: Peta lokasi penelitian.

\section{Alat dan Bahan Penelitian}

Penelitian ini membutuhkan bahan dan alat yang menunjang agar kegiatan penelitian dapat berjalan dengan baik dengan hasil yang memuaskan. Adapun alat dan bahan yang digunakan dalam penelitian ini adalah sebagai berikut: Meteran jahit $(150 \mathrm{~m})$, tali rafia, GPS (Global Positioning System), meteran rol (50 m), kamera handphone, alat tulis menulis, buku identifikasi jenis mangrove (Noor $d k k$., 2006). 


\section{Metode Penelitian}

Untuk pengambilan data vegetasi mangrove dilakukan sebanyak enam stasiun dengan kondisi yang berbeda, sebagai berikut: Stasiun 1: Parigi Sulap, Stasiun 2: Desa Tuyat, Stasiun 3: Desa Tandu, Stasiun 4: Desa Diat, Stasiun 5: Desa Solog dan Stasiun 6: Pelabuhan PT. Conch. Prosedur pengambilan data dan pengamatan vegetasi mangrove sesuai dengan metode yang telah dipublikasikan oleh Bengen (2001) (Lihat Gambar 2).

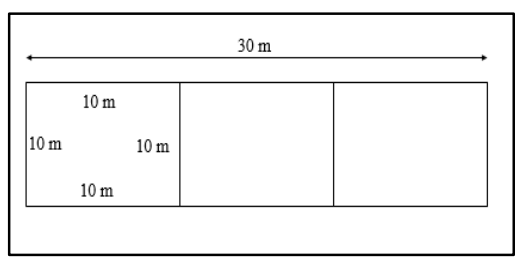

Gambar 2. Skema penempatan petak contoh/plot.

Adapun prosedur pengambilan data vegetasi mangrove adalah sebagai berikut:

Pengambilan data pada satu stasiun dibuat plot dengan ukuran $10 \times 10 \mathrm{~m}^{2}$ dengan tiga kali ulangan yang terbuat dari tali plastik dengan mengukur diameter pohon pada ketiggian dada (DBH) yang memiliki lingkar batang minimal $16 \mathrm{~cm}$. Identifikasi jenis mangrove dilakukan berdasarkan Noor $d k k$. (2006), serta dihitung juga lingkar batang dan jumlah pohon di setiap plot.

\section{Pengambilan data vegetasi mangrove}

Perhitungan untuk mendapatkan data vegetasi mangrove adalah dengan mengetahui $\mathrm{DBH}$ (diameter at breast height). Pengukuran vegetasi pohon mangrove menggunakan metode plot (Dharmawan dan Pramudji, 2014):

1. Dalam setiap plot $10 \times 10 \mathrm{~m}^{2}$ dilakukan pengukuran diameter batang pohon mangrove (keliling batang), pengukuran dilakukan dengan menggunakan meteran pada seluruh pohon yang berada di dalam plot.

2. Mengidentifikasi setiap jenis pohon yang berada di setiap plot berdasarkan buku identifikasi (Noor dkk., 2006). Jika terjadi keraguan dalam identifikasi, maka dapat dilakukan pemotretan bahkan mengambil bagian tanaman yaitu akar, batang, daun, bunga dan buah untuk diidentifikasi lebih lanjut di laboratorium atau dengan bantuan literatur lainnya.

3. Pengukuran diameter setinggi dada pada berbagai kondisi pohon pada saat melakukan penelitian dapat mengacu pada Gambar 3 berikut:
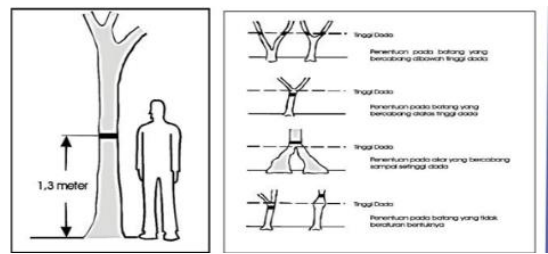

Gambar 3. Ilustrasi posisi pengukuran lingkar batang pohon mangrove berdasarkan pada Keputusan Menteri Lingkungan Hidup RI No. 201 tahun 2004 tentang Kriteria Baku dan Pedoman Penentuan Kerusakan Mangrove.

\section{Analisis Data}

\section{Analisis Struktur Komunitas Mangrove}

Dalam mengetahui gambaran struktur komunitas mangrove, data dapat diolah dan dianalisa dengan cara menghitung nilai-nilai kerapatan spesies, kerapatan relatif spesies, frekuensi spesies, frekuensi relatif spesies, penutupan spesies, penutupan relatif spesies, indeks nilai penting, indeks keanekaragaman spesies (Bengen, 2004; Kusmana dkk., 2003; Kusumastanto dkk., 2002 dalam Paruntu dkk., 2017), sebagai berikut:

\section{a) Kerapatan jenis (Di)}

Kerapatan spesies (Di) adalah jumlah individu jenis i dalam suatu unit area yang dinyatakan sebagai berikut:

$D i=\frac{n i}{A}$

\section{Keterangan:}

$\mathrm{Di}=$ Kerapatan spesies ke-i

$\mathrm{ni}=$ jumlah total individu dari jenis ke-i (tegakan) dalam transek kuadrat 
$A=$ Luas transek kuadran $\left(\mathrm{m}^{2}\right)$.

b) Kerapatan relatif (RDi)

Kerapatan relatif jenis (RDi) adalah perbandingan antara jumlah individu spesies $i$ (ni) dan jumlah total individu seluruh jenis $(\Sigma N)$ dengan formula sebagai berikut:

$R D i=\frac{n i}{\sum n} \times 100$

\section{Keterangan:}

$\mathrm{RDi}=$ Kerapatan relative jenis (\%)

$\mathrm{ni}=$ Jumlah total individu seluruh jenis ke-I (ind.)

$\Sigma \mathrm{n}=$ Jumlah total tegakan seluruh jenis ke-i (ind.).

c) Frekuensi jenis (Fi)

Frekuensi jenis (Fi) adalah peluang ditemukannya jenis i dalam petak contoh yang diamati:

$F i=\frac{p i}{\sum P}$

$\mathrm{Fi}=$ Frekuensi jenis ke-i

$\mathrm{Pi}=$ Jumlah petak dimana ditemukan jenis ke- $\mathrm{i}$

$\Sigma \mathrm{p}=$ Jumlah total petak sampel yang dibuat.

d) Frekuensi Relatif Jenis (RFi)

Frekuensi relatif (RFi) adalah perbandingan antara frekuensi jenis ke-i dengan jumlah frekuensi seluruh jenis. Frekuensi relatif (RFi) dapat dihitung menggunakan persamaan:

$R F i=\frac{F i}{\sum F} \times 100$

\section{Keterangan:}

$\mathrm{RFi}=$ Frekuensi relatif jenis (\%)

$\mathrm{Fi}=$ Frekuensi jenis

$\Sigma F=$ Jumlah frekuensi untuk seluruh jenis.

e) Penutupan spesies (Ci)

Penutupan jenis ( $\mathrm{Ci}$ ) adalah luas penutupan jenis ke-i dalam suatu unit area tertentu, dengan menggunakan rumus, yaitu:

$C i=\frac{\sum B A}{A}$

\section{Keterangan:}

$\mathrm{Ci}=$ Penutupan jenis $\mathrm{k}-\mathrm{i}$

$\Sigma \mathrm{BA}=$ Diameter batang setinggi jenis

$\mathrm{A}=$ Luas total area pengambilan contoh $\left(\mathrm{m}^{2}\right)$

\section{f) Penutupan Relatif (RCi)}

Penutupan Relatif ( $\mathrm{RCi}$ ) yaitu perbandingan antara penutupan jenis ke-i dengan luas total penutupan untuk seluruh spesies. Penutupan relatif (RCi) dapat dihitung menggunakan persamaan:

$R C i=\frac{C i}{\sum C} \times 100$

\section{Keterangan:}

$\mathrm{RCi}=$ Penutupan relatif $(\%)$

$\mathrm{Ci}=$ Penutupan jenis ke- $\mathrm{i}$

$\mathrm{C}=$ Penutupan total untuk seluruh jenis

$A=$ Luas total area pengambilan contoh $\left(\mathrm{m}^{2}\right)$

g) Indeks Nilai Penting (INP)

Indeks Nilai Penting (INP) adalah penjumlahan nilai relatif $(R D i)$, frekuensi relatif $(\mathrm{RFi})$ dan penutupan relatif $(\mathrm{RCi})$ dari mangrove dapat dihitung menggunakan persamaan:

$I N P=R D i+R F i+R C i$

\section{Keterangan:}

$\mathrm{INP}=\sum \mathrm{RDi}, \mathrm{RFi}, \mathrm{RCi}(\%)$

$\mathrm{RDi}=$ Kerapatan relatif

$\mathrm{RFi}=$ Frekuensi relatif

$\mathrm{RCi}=$ Penutupan relatif

Indeks nilai penting suatu jenis berkisar antara 0 - 300. Nilai penting ini memberikan gambaran tentang peranan suatu jenis mangrove dalam ekosistem dan dapat juga digunakan untuk mengetahui dominasi suatu jenis dalam komunitas.

\section{Hasil dan Pembahasan \\ Jenis mangrove \\ Berdasarkan penelitian ditemukan 5 jenis mangrove di 6 stasiun, yaitu Rhizophora apiculate, Rhizophora mucronata, Sonneratia alba, Xylocarpus granatum, dan Bruguirea gymnorhiza, dan jenis mangrove yang paling mendominasi pada ke 6 stasiun adalah jenis Rhizophora apiculata.}

Hasil Analisis Struktur Komunitas Mangrove 


\section{Kerapatan jenis dan kerapatan relatif jenis}

Kerapatan jenis mangrove adalah jumlah tegakkan jenis i dalam suatu area sedangkan kerapatan relatif jenis mangrove adalah perbandingan antara jumlah tegakkan jenis i dengan jumlah total tegakkan seluruh jenis mangrove (Bengen, 2000). Kerapatan jenis dan kerapatan relatif masing-masing jenis mangrove pada stasiun 1, adalah: $R$. mucronata 0,03 ind. $/ \mathrm{m}^{2}$ dan $27,59 \%, R$. apiculata 0,03 ind. $/ \mathrm{m}^{2}$ dan $27,59 \%$, dan $S$. alba 0,04 ind. $/ \mathrm{m}^{2}$ dan 44,83\%; stasiun 2, adalah: $R$. mucronata 0,11 ind. $/ \mathrm{m}^{2}$ dan $62,96 \%, X$ granatum 0,02 ind. $/ \mathrm{m}^{2}$ dan $11,11 \%$, B. gymnorhiza 0.05 ind. $/ \mathrm{m}^{2}$ dan 25.93\%; stasiun 3, adalah: $R$. mucronata 0.02 ind. $/ \mathrm{m}^{2}$ dan $59,65 \%, R$. apiculata 0,11 ind. $/ \mathrm{m}^{2}$ dan $59,65 \%, X$. granatum 0,02 ind. $/ \mathrm{m}^{2}$ dan 10,53\%. stasiun 4, adalah: R. mucronata 0,06 ind. $/ \mathrm{m}^{2}$ dan $36,96 \%, R$. apiculata 0,04 ind. $/ \mathrm{m}^{2}$ dan $26,09 \%$, B. gymnorhiza 0,06 ind. $/ \mathrm{m}^{2}$ dan 36,96\%; Stasiun 5, adalah: $R$. mucronata 0,06 ind. $/ \mathrm{m}^{2}$ dan $32,69 \%, R$. apiculata 0,06 ind. $/ \mathrm{m}^{2}$ dan $36,64 \%, X$. granatum 0,02 ind. $/ \mathrm{m}^{2}$ dan $9,62 \%$, B. gymnorhiza 0,04 ind./ $/ \mathrm{m}^{2}$ dan $21,15 \%$; Stasiun 6, adalah $R$. mucronata 0.07 ind. $/ \mathrm{m}^{2}$ dan $22 \%, R$. apiculata 0,04 ind. $/ \mathrm{m}^{2}$ dan $42 \%, X$. granatum 0,04 ind. $/ \mathrm{m}^{2}$ dan $22 \%, B$. gymnorhiza
0,02 ind. $/ \mathrm{m}^{2}$ dan $14 \%$. Stasiun yang mempunyai kerapatan mangrove tertinggi yaitu pada stasiun 2 , yaitu $R$. mucronata $0,11 \mathrm{ind} . \mathrm{m}^{2}$ dan $62,96 \%$ dan terendah pada stasiun 3 , yaitu $R$. mucronata 0,02 ind. $/ \mathrm{m}^{2}$ dan 8,77\%. (Tabel 1 \& Gambar 4).

Tingginya nilai kerapatan jenis ditentukan oleh banyaknya jumlah individu, begitu pula sebaliknya jika jumlah individunya sedikit, maka nilai kerapatannya rendah. Kerapatan jenis tertinggi disebabkan oleh subsrat yang cocok, dan kemampuan beradaptasi dengan kondisi lingkungan. Faktor yang menyebabkan pertumbuhan mangrove relatif jarang adalah kondisi akar pohon yang tergolong besar, sehingga pertumbuhan menjadi kurang optimal (Agustini dkk., 2016). Semakin rapat suatu ekosistem mangrove akan semakin baik dalam mereduksi gelombang dan menahan sedimen ataupun sampah, akan tetapi hal ini juga akan berdampak buruk bagi pertumbuhan dan regenerasi mangrove. Minimnya penyinaran matahari akan memperlambat proses fotosintesis yang membuat semai ataupun tumbuhan pacang sulit untuk berkembang (Schaduw, 2016).

Tabel 1. Kerapatan jenis (Di)

\begin{tabular}{|l|c|c|c|c|c|c|}
\hline \multicolumn{7}{|c|}{ Kerapatan Jenis $\left(\mathbf{I n d} / \mathbf{m}^{2}\right)$} \\
\hline Jenis & S1 & S2 & S3 & S4 & S5 & S6 \\
\hline R. mucronata & 0.03 & 0.11 & 0.02 & 0.06 & 0.06 & 0.07 \\
\hline S. apiculata & 0.03 & & 0.11 & 0.04 & 0.06 & 0.04 \\
\hline X. granatum & 0.04 & & & & & \\
\hline B. gymnorhiza & & 0.02 & 0.02 & & 0.02 & 0.04 \\
\hline
\end{tabular}




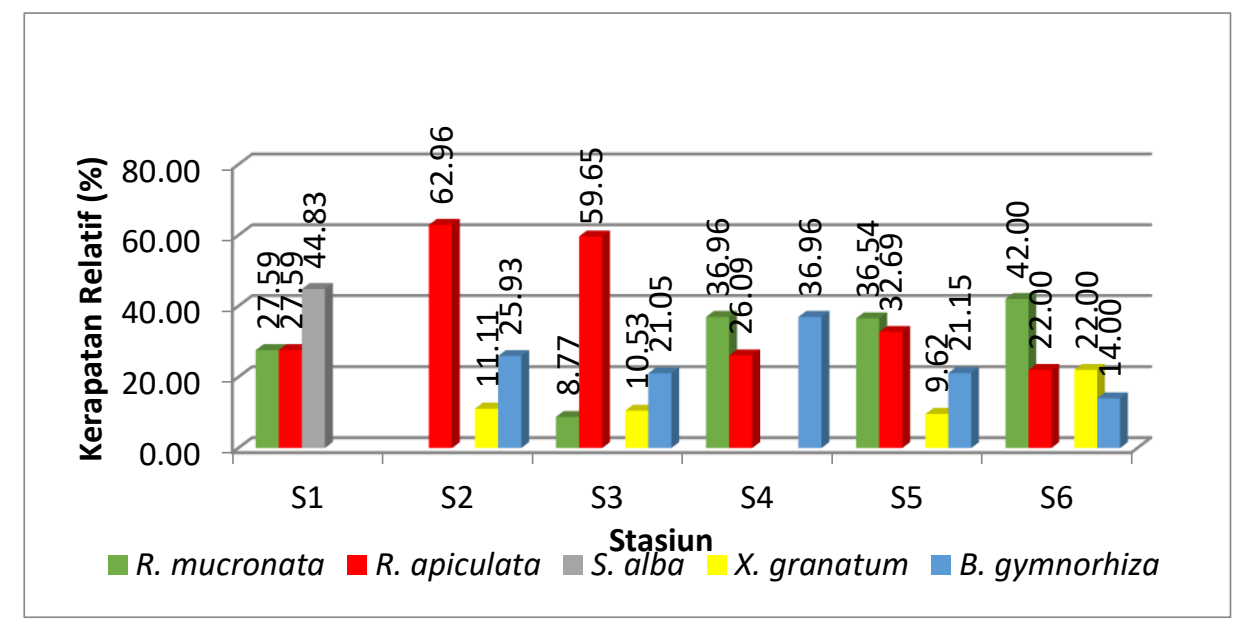

Gambar 4. Kerapatan relatif jenis

\section{Frekuensi jenis dan Frekuensi relatif jenis}

Frekuensi jenis adalah peluang ditemukannya jenis ke i dalam petak contoh yang diamati, sedangkan frekuensi relatif jenis yaitu perbandingan antara frekuensi jenis ke-i dan jumlah frekuensi untuk seluruh jenis (Bengen, 2000). Hasil penelitian menunjukkan bahwa frekuensi jenis dan frekuensi relatif pada Stasiun 1, adalah: $R$. mucronata 0,33 dan $20 \%$, $R$. apiculata 0,67 dan $40 \%, S$. alba 0,67 dan 40\%; Stasiun 2, adalah: $R$. apiculata 1 dan $33,33 \%, X$. granatum 1 dan $33,33 \%, B$. gymnorhiza 1 dan 33,33\%; Stasiun 3, adalah: $R$. mucronata 0,75 dan $33,33 \%, R$. apiculata 0,75 dan $33,33 \%$, X. granatum 0,05 dan $22,22 \%, B$. gymnorhiza 0,25 dan 11,11\%; Stasiun 4, adalah: R. mucronata 1 dan 33,33, R. apiculata 1 dan 33,33\%, B. gymnorhiza 1 dan 33,33\%; Stasiun 5, adalah: $R$. mucronata 0,75 dan $33,33 \%, R$. apiculata 0,75 dan $33,33 \%, X$ granatum 0,25 dan $11,11 \%$, B. gymnorhiza 0,5 dan $22,22 \%$; dan Stasiun 6, adalah: $R$. mucronata 0,75 dan $25 \%, R$. apiculata 0,75 dan $25 \%, X$. granatum 0,75 dan $25 \%$, B. gymnorhiza 0.75 dan $25 \%$. Nilai frekuensi jenis dan frekuensi relatif jenis tertinggi pada ke 6 stasiun adalah terdapat pada stasiun 4, yaitu $R$. mucronata dan $33.33 \%$, sedangkan terendah pada stasiun 5 , yaitu B. gymnorhiza 0,5 dan 25.00\% (Tabel 2 \& Gambar 5).

Tabel 2. Frekunsi jenis (Fi)

\begin{tabular}{|l|c|c|c|c|c|c|}
\hline \multicolumn{7}{|c|}{ Frekunsi Jenis (Fi) } \\
\hline Jenis & S1 & S2 & S3 & S4 & S5 & S6 \\
\hline R. Mucronata & 0.33 & & 0.75 & 1.00 & 0.75 & 0.75 \\
\hline R. Apiculata & 0.67 & 1.00 & 0.75 & 1.00 & 0.75 & 0.75 \\
\hline S. Alba & 0.67 & & & & & \\
\hline X. granatum & & 1.00 & 0.50 & & 0.25 & 0.75 \\
\hline B. gymnorhiza & & 1.00 & 0.25 & 1.00 & 0.5 & 0.75 \\
\hline Total & 1.67 & 3.00 & 2.25 & 3.00 & 2.25 & 3.00 \\
\hline
\end{tabular}




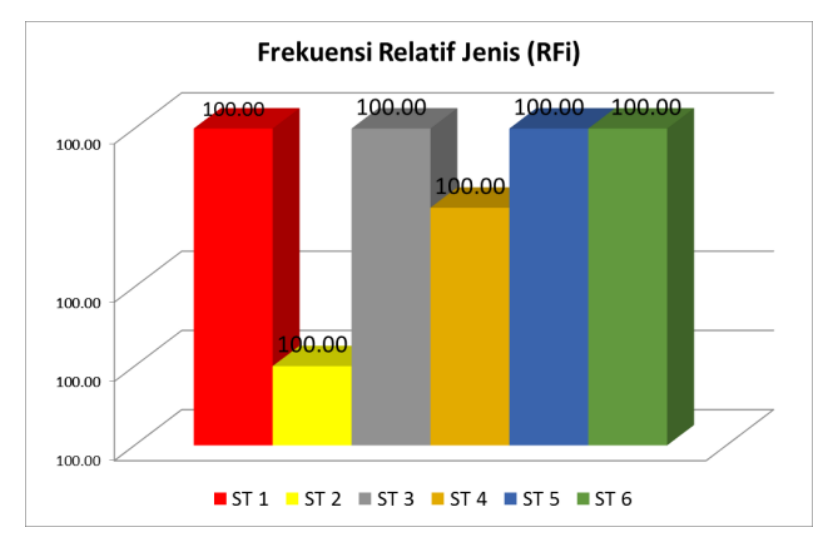

Gambar 5. Frekuensi relatif jenis (RFi)

\section{Penutupan jenis dan penutupan relatif jenis}

Nilai penutupan jenis dan penutupan relatif jenis pada stasiun 1 , yaitu $R$. mucronata $1,087 \mathrm{~cm}^{2} / \mathrm{m}^{2}$ dan $34,22 \%$, $R$. apiculata 0,85 $\mathrm{cm}^{2} / \mathrm{m}^{2}$ dan $21,42 \%$, S. alba $1,26 \mathrm{~cm}^{2} / \mathrm{m}^{2}$ dan 44,36\%; Stasiun 2, yaitu $R$. apiculata 0,89 $\mathrm{cm}^{2} / \mathrm{m}^{2}$ dan $12,88 \%$, X. granatum $3,06 \mathrm{~cm}^{2} / \mathrm{m}^{2}$ dan $44,41 \%$, B. gymnorhiza 2,94 dan $42,41 \%$; Stasiun 3 yaitu $R$. Mucronata $4,67 \mathrm{~cm}^{2} / \mathrm{m}^{2}$ dan $45,11 \%, R$. apiculata $2,29 \mathrm{~cm}^{2} / \mathrm{m}^{2}$ dan $22,07 \%$, X. granatum $2,49 \mathrm{~cm}^{2} / \mathrm{m}^{2}$ dan $24,00 \%, B$. gymnorhiza $0,91 \mathrm{~cm}^{2} / \mathrm{m}^{2}$ dan $8.82 \%$; Stasiun 4 yaitu $R$. mucronata $2,95 \mathrm{~cm}^{2} / \mathrm{m}^{2}$ dan $29,51 \%, R$. apiculata $3,48 \mathrm{~cm}^{2} / \mathrm{m}^{2}$ dan $34,88 \%$, $B$. gymnorhiza $3,56 \mathrm{~cm}^{2} / \mathrm{m}^{2}$ dan $35,61 \%$; Stasiun 5 yaitu $R$. mucronata $4,28 \mathrm{~cm}^{2} / \mathrm{m}^{2}$ dan $27,34 \%, R$. apiculata $4,84 \mathrm{~cm}^{2} / \mathrm{m}^{2}$ dan $30,91 \%$, $X$. granatum 2,24 dan $14,31 \%$, B. gymnorhiza $4,30 \mathrm{~cm}^{2} / \mathrm{m}^{2}$ dan 27,44\%; Stasiun 6 jenis $R$. mucronata 3,45 $\mathrm{cm}^{2} / \mathrm{m}^{2}$ dan $26,81 \%$, $R$. apiculata $2,68 \mathrm{~cm}^{2} / \mathrm{m}^{2}$ dan $20,82 \%, X$. granatum $3,90 \mathrm{~cm}^{2} / \mathrm{m}^{2}$ dan $30,36 \%$, B. gymnorhiza $2,83 \mathrm{~cm}^{2} / \mathrm{m}^{2}$ dan $22,01 \%$. Penutupan relative jenis menunjukkan besaran tutupan jenis dalam menempati area pada suatu plot area, jika nilainya mendekati $100 \%$ dapat dikatakan bahwa suatu jenis tersebut hampir ada di semua cover plot area. Nilai penutupan jenis dan penutupan relatif jenis tertinggi pada stasiun 5 , yaitu $R$. mucronata 4,84 $\mathrm{cm}^{2} / \mathrm{m}^{2}$ dan $30,91 \%$, sedangkan nilai terendah pada stasiun 2, yaitu $R$. apiculata $0,89 \mathrm{~cm}^{2} / \mathrm{m}^{2}$ dan 12,88\% (Tabel 3 dan Gambar 6).

Nilai frekuensi dipengaruhi oleh nilai petak dimana ditemukannya jenis mangrove. Nilai frekuensi spesies yang diperoleh memperlihatkan bahwa peluang akan kehadiran mangrove di setiap lokasi sangat besar, selain itu kemunculan setiap spesies juga besar, sehingga memberikan peluang akan kestabilan mangrove di lokasi ini (Bismark dkk., 2008).

Tabel 3. Penutupan Jenis (Ci)

\begin{tabular}{|l|c|c|c|c|c|c|}
\hline \multicolumn{7}{|c|}{ Penutupan Jenis $\left(\mathbf{c m}^{2} / \mathbf{m}^{2}\right)$} \\
\hline Jenis & $\mathrm{S} 1$ & $\mathrm{~S} 2$ & $\mathrm{~S} 3$ & $\mathrm{~S} 4$ & $\mathrm{~S} 5$ & $\mathrm{~S} 6$ \\
\hline R. mucronate & 1.08 & & 2.29 & 3.48 & 4.84 & 2.68 \\
\hline R. apiculata & 1.72 & 0.89 & 4.67 & 2.95 & 4.28 & 3.45 \\
\hline S. alba & 2.23 & & & & & \\
\hline X. granatum & & 3.06 & 2.49 & & 2.24 & 3.90 \\
\hline B. gymonorhisa & & 2.94 & 0.91 & 3.56 & 4.30 & 2.83 \\
\hline
\end{tabular}




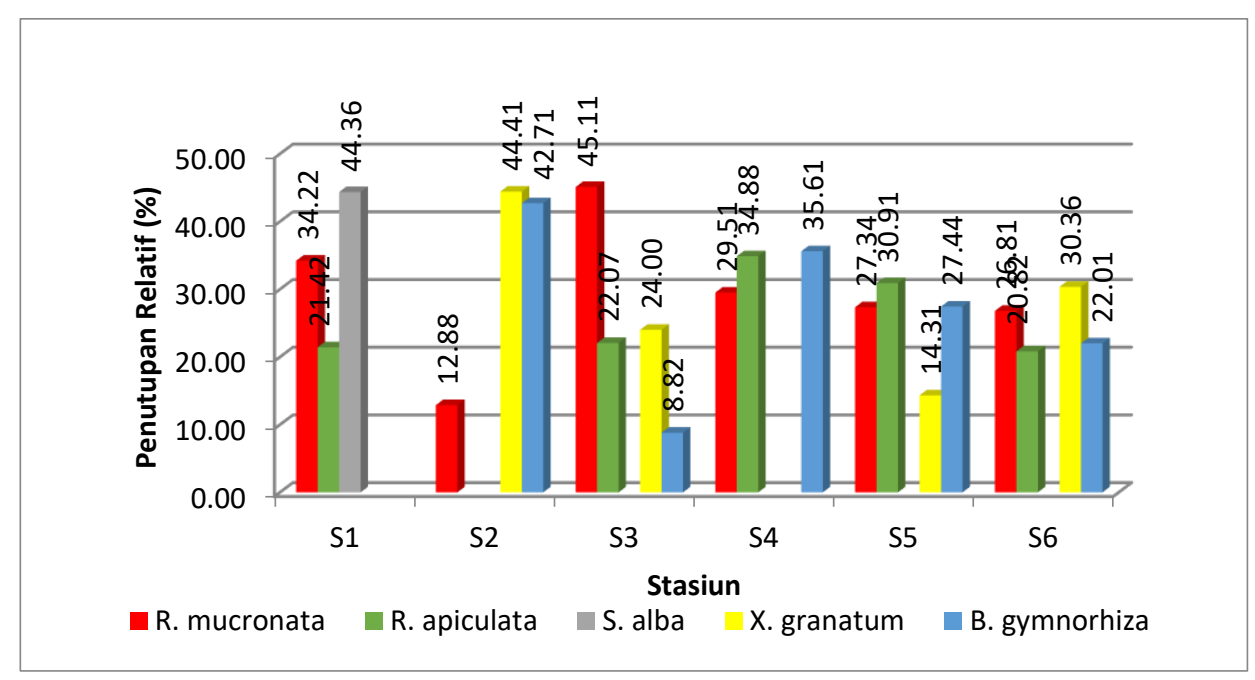

Gambar 6. Penutupan relatif jenis.

Penutupan jenis dan penutupan relatif jenis tertinggi yaitu $R$. mucronata menunjukkan bahwa jenis ini memiliki diameter pohon dan produktivitas yang besar, sehingga nilai penutupan jenis yang diperoleh juga tinggi. Faktor-faktor yang mempengaruhi nilai tutupan suatu jenis ialah lingkaran batang pohon dan basal area dalam satu lokasi pengambilan sampel (Lahabu dkk., 2015). Faktor yang paling berpengaruh dalam menentukan besarnya diameter batang adalah jenis umur pohon, dengan lamanya pertumbuhan umur suatu pohon, maka pohon tersebut akan bertambah besar.

\section{Indeks Nilai Penting}

Indeks nilai penting (INP) mangrove pada stasiun 1, yaitu $R$. mucronata $69,01 \%, R$. apiculata $101,80 \%$, S. alba 129,19\%; stasiun 2, yaitu $R$. apiculata $109,18 \%, \quad X$. granatum $88,86 \%$, B. gymnorhiza $68,63 \%$; stasiun 3, yaitu R. mucronata $64,18 \%$, R. apiculata $138,09 \%, X$. granatum $56,75 \%$, B. gymnorhiza $40,98 \%$; stasiun 4, yaitu $R$. mucronata $105,17 \%, R$. apiculata $88,93 \%$, B. gymnorhiza 105,90\%; stasiun 5, yaitu $R$. mucronata $100,79 \%, R$. apiculata $93,36, \quad X$. granatum $35,03 \%, B$. gymnorhiza 70,83\%; stasiun 6, yaitu $R$. mucronata $87,82 \%, \quad R$. apiculata $73,81 \%, X$. granatum $77,36 \%$, B. gymnorhiza $61,01 \%$. Indeks nilai penting tertinggi pada stasiun 3 , yaitu $R$. apiculata $138,09 \%$ dan nilai terendah pada stasiun 5 , yaitu $X$. granatum $35,05 \%$ (Tabel 4).

Semakin tinggi indeks nilai penting, mengindikasikan bahwa jenis tersebut lebih berhasil menempati area dari pada spesies yang lain (Paruntu dkk., 2017). Pada lokasi penelitian ini bawah $R$. apiculata merupakan jenis mangrove yang mendominasi kawasan tersebut. Jika dominasi lebih terkonsentrasi pada satu jenis, nilai indeks dominasi akan meningkat dan sebaliknya jika beberapa jenis mendominasi secara bersama-sama, maka nilai indeks dominasi akan rendah (Indriyanto, 2006 dalam Parmadi dkk., 2016). Jenis ini lebih unggul dalam memanfaatkan sumber daya mangrove di kawasan ini atau lebih dapat menyesuaikan diri dengan lingkungan setempat.

Secara keseluruhan jenis $R$. mucronata, $R$. apiculata, X. granatum dan B. gymnorhiza ditemukan pada setiap plot/petak pengamatan. Hal ini menunjukkan bahwa jenis ini memiliki penyebaran jenis dan keberadaan yang lebih 
tinggi, jika dibandingkan dengan jenis yang lainnya.

Tabel 4. Indeks nilai Penting

\begin{tabular}{|l|c|c|c|c|c|c|}
\hline \multicolumn{7}{|c|}{ Indeks Nilai Penting (\%) } \\
\hline Jenis & $\mathrm{S} 1$ & $\mathrm{~S} 2$ & $\mathrm{~S} 3$ & $\mathrm{~S} 4$ & $\mathrm{~S} 5$ & $\mathrm{~S} 6$ \\
\hline R. Mucronata & 69.01 & & 64.18 & 105.17 & 100.79 & 87.82 \\
\hline R. Apiculata & 101.80 & 109.18 & 138.09 & 88.93 & 93.36 & 73.81 \\
\hline S. Alba & 129.19 & & & & & \\
\hline X. granatum & & 88.86 & 56.75 & & 35.03 & 77.36 \\
\hline B. gymnorhiza & & 68.63 & 40.98 & 105.90 & 70.82 & 61.01 \\
\hline
\end{tabular}

\section{Kesimpulan}

\section{Kesimpulan Dan Saran}

Kesimpulan hasil penelitian ini adalah:

1. Ditemukan 5 jenis mangrove: $R$. apiculata, R. mucronata, S. alba, X. granatum, dan $B$. gymnorhiza.

2. Kerapatan relatif jenis tertinggi pada stasiun 2 , yaitu $R$. mucronate $62,96 \%$, sedangkan nilai terendah pada stasiun 3 , yaitu $R$. mucronata $8,77 \%$.

3. Frekuensi relatif jenis tertingi pada stasiun 4 , yaitu $R$. mucronata $33.33 \%$, sedangkan nilai terendah pada stasiun 5 , yaitu $B$. gymnorhiza $25.00 \%$.

4. Penutupan relatif jenis tertinggi pada stasiun 5 , yaitu $R$. mucronata $30,91 \%$, sedangkan terendah pada stasiun 2, yaitu $R$. apiculata $12,88 \%$.

5. Indeks nilai penting tertinggi pada stasiun 3 , yaitu $R$. apiculata $138,09 \%$ dan nilai terendah pada stasiun 5 , yaitu $X$. granatum $35,05 \%$.

\section{Saran}

Berdasarkan penelitian yang telah dilakukan, peneliti menyarankan:

1. Diperlukan adanya penelitian lebih dalam serta kepedulian mengenai kondisi hutan mangrove di kawasan sekitar PT. Conch. Kec. Lolak.

2. Perlu adanya pembatasan perijinan kawasan mangrove menjadi kawasan ekonomi dan industri.
3. Harus adanya penguatan penegakan peraturan tentang pemanfaatan dan pengelolaan mangrove secara berkelanjutan.

\section{DAFTAR PUSTAKA}

Agustini, N. Tri., Ta'aladin, Z dan Purnama, D. 2016. "Struktur Komunitas Mangrove Di Desa Kahyapu Pulau Enggano." Program Studi Ilmu Kelautan Fakultas Pertanian Universitas Bengkulu, Bengkulu. EISSN:2527-5186 Jurnal Enggano Vol 1 No.1.

Bismark, M., Subiandono, E. dan Heriyanto, N.M. 2008. "Keragaman dan potensi jenis serta kandungan karbon hutan mangrove di sungai subelen siberut, sumatra barat". Jurnal Penelitian Hutan dan Konservasi. 5(3): 297-306.

Bengen DG. (2000). "Sinopsis Ekosistem Dan Sumberdaya Wilayah Pesisisr." Pusat Kajian Sumberdaya Pesisir dan Lautan IPB.hal 1:2.

Bengen, D.G. 2001. "Pedoman Teknis Pengenalan dan Pengelolaan Ekosistem Mangrove. Pusat Kajian Sumberdaya Pesisir dan Lautan-Institut Pertanian Bogor." Bogor, Indonesia. 
Dharmawan, I .W. E., dan Pramudji. 2014. "Panduan Monitoring Status Ekosistem Mangrove". COREMAP-CTI. Pusat Penelitian Oseanografi. Lembaga IImu Pengetahuan Indonesia. 46 hal.

Indriyanto, 2006. "Ekologi Hutan. Jakarta: Penerbit PT Bumi Aksara."

Lahabu, Y., Joshian N.W. Schaduw, dan Agung B. Windarto. 2015. "Kondisi Ekologi Mangrove Di Pulau Mantehage Kecamatan Wori Kabupaten Minahasa Utara Provinsi Sulawesi Utara". Jurnal Pesisir Dan Laut Tropis 2 (1): 2015.

Nurrahman, Y. A, O. S Djunaedi, and R Rostika. 2012. "Struktur Dan Komposisi Vegetasi Mangrove Di Pesisir Kecamatan Sungai Raya Kepulauan Kabupaten Bengkayang Kalimantan Barat". Perikanan Dan Kelautan 3 (1): 99-107.

Noor, Yus Rusila, M. Khazali, and I N.N. Suryadiputra. 2006. Panduan Pengenalan MANGROVE Di Indonesia. PHKA/WI-IP: Bogor.

Paruntu, C.P., A.B. Windarto, dan A.P. Rumengan. 2017. "Karakteristik Komunitas Mangrove Desa Motandoi Kecamatan Pinolosian Timur Kabupaten Bolaang Mongondow Selatan Provinsi Sulawesi Utara". Jurnal Pesisir Dan Laut Tropis 1 (2): 53-65.

Parmadi, J.C, E. H,. Dewiyanti, I; Karina, S. 2016. "Indeks Nilai Penting Vegetasi Mangrove Di Kawasan Kuwalah Idi,
Kabupaten Aceh Timur." Jurnal IImia Mahasiswa Kelautan Dan Perikanan Unsyiah. Vol 1 No. 1: 82-95.

Sefle, L., Pakasi E.S., Kamagi, B.E.Y dan R. Kawulusan 2013. ". Klasifikasi Kemampuan Lahan Dengan Menggunakan Sistem Informasi Geografis Di Kecamatan Lolak Kabupaten Bolaang Mongondow." Vol. 2 No. (4).

Schaduw, J. N. W. 2016. " Struktur Komunitas dan Persentase Penutupan Kanopi Mangrove Pulau Salawati Kabupaten Kepulauan Raja Ampat Provinsi Papua Barat". Majalah Geografi Indonesia. Vol. 33 (1): 26-34. 